\title{
Penetapan Tersangka pada Peradilan Koneksitas dalam Perkara Tindak Pidana Korupsi
}

\author{
Yusnita Mawarni \\ Airlangga University, Indonesia \\ m.yusnita44@yahoo.com
}

\begin{abstract}
Corruption is a criminal act, not only committed by civilians, but also by military members. Members of the military utilize procedural law called connectivity, in which cases are examined through the mechanism of connectivity. Neglecting the mechanism of connectivity results in uncertain legal implementation. The arrangement of the existing connectivity mechanism within the legislation includes the establishment of a permanent team: public court officials and military court officials whose implementation is considered complicated. While one official's handling of cases would be considered corrupt, they instead commit the act of splitsing (the separated settlement of the case). The Corruption Eradication Commission (KPK), as an institution, has the authority to control and coordinate corruption criminal cases. In the case of a criminal act of connectivity, related to corruption cases handled by KPK investigators and military investigators, although it may not be examined through the mechanism of connectivity, it is still valid because the determination of the suspect on the offender is based on sufficient initial evidence. Yet, this connectivity mechanism is necessary so that the examination of the case will be a set of intact connectivity, stated in the legislation that regulates the handling of the crime of connectivity in order to sustain justice for all parties.
\end{abstract}

KEYWORDS: Corruption, Connectivity, Determination of Suspects.

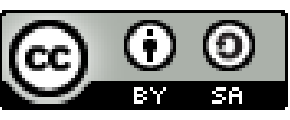

Copyright $\odot 2018$ by Author(s)

This work is licensed under a Creative Commons Attribution-ShareAlike 4.0

International License. All writings published in this journal are personal views of the authors and do not represent the views of this journal and the author's affiliated institutions.

\section{HOW TO CITE:}

Mawarni, Yusnita. "Penetapan Tersangka pada Peradilan Koneksitas dalam Perkara Tindak Pidana Korupsi” (2018) 5:2 Lentera Hukum 227-246.

Submitted: May 08, 2018 Revised: July 09, 2018 Accepted: July 29, 2018 


\section{PENDAHULUAN}

Di Indonesia, korupsi merupakan tindak pidana yang sangat merugikan keuangan atau perekonomian negara dan menghambat pembangunan nasional. ${ }^{1}$ Korupsi tidak hanya dilakukan oleh masyarakat sipil saja akan tetapi juga dilakukan oleh anggota militer yang memiliki hukum acara sendiri maupun dilakukan secara bersama-sama oleh orang yang tunduk dalam peradilan umum dan orang yang tunduk dalam peradilan militer yang dinamakan perkara koneksitas. ${ }^{2}$ Indonesia merupakan negara hukum sebagaimana dalam Pasal 1 ayat (3) Undang-Undang Dasar Negara Republik Indonesia Tahun 1945 (UUD 1945). Oleh sebab itu, segala sesuatunya harus didasarkan pada hukum. ${ }^{3}$ Sebagai negara hukum, Indonesia menjamin adanya kepastian dengan menggunakan landasan hukum sebagai pedoman dalam mengatur masyarakatnya termasuk pengaturan terkait penanganan tindak pidana korupsi.

Adapun penanganan tindak pidana korupsi dimulai dari penyelidikan, penyidikan, penuntutan, persidangan dan eksekusi. Penetapan tersangka merupakan salah satu bagian dari proses penanganan tindak pidana korupsi setelah selesainya penyidikan atau setelah terdapat bukti permulaan yang cukup sebagaimana diatur di dalam peraturan perundangundangan yang berlaku. Penetapan tersangka setelah Putusan Mahkamah Konstitusi Nomor 21/PUU-XII/2014 masuk dalam obyek praperadilan. Penetapan tersangka sebagai salah satu objek praperadilan bertujuan agar perlakuan terhadap seseorang dalam proses pidana memperhatikan hak tersangka sebagai manusia yang mempunyai harkat, martabat dan kedudukan yang sama di hadapan hukum. ${ }^{4}$

Dalam perkara korupsi yang melibatkan tersangka dalam lingkup peradilan umum dan peradilan militer, diatur dalam Undang-Undang Nomor 8 Tahun 1981 tentang Hukum Acara Pidana (KUHAP). Mekanisme pemeriksaan koneksitas juga diatur di dalam Undang-Undang Nomor 31 Tahun 1997 tentang Peradilan Militer (UU Peradilan Militer).

Adapun pengaturan mekanisme koneksitas dalam KUHAP maupun UU Peradilan Militer salah satu prosedur penanganan tindak pidana korupsi yang melibatkan tersangka yang masuk ruang lingkup peradilan umum dan peradilan militer adalah dibentuknya tim tetap. Namun, terdapat pemeriksaan perkara tindak pidana korupsi yang melibatkan masyarakat sipil dan anggota militer. Ada yang diperiksa melalui mekanisme koneksitas maupun tidak diperiksa tanpa melalui mekanisme koneksitas tersebut. Contoh perkara korupsi yang melibatkan tersangka yang masuk ruang lingkup peradilan umum dan

1 Romli Atmasasmita, Korupsi, good governance, dan komisi anti korupsi di Indonesia (Departemen Kehakiman dan HAM RI, Badan Pembinaan Hukum Nasional, 2002)., hlm. 9.

2 Indonesia Badan Pembinaan Hukum Nasional, Analisis dan evaluasi hukum tentang putusan pengadilan militer dalam perkara koneksitas (Badan Pembinaan Hukum Nasional, Departemen Kehakiman, 1996)., hlm. 2.

3 Evi Hartanti, Tindak pidana korupsi (Sinar Grafika, 2005)., hlm. 17.

4 WANDA RARA FAREZHA, "ANALISIS PUTUSAN HAKIM PRAPERADILAN DALAM PERKARA TINDAK PIDANA KORUPSI (Studi Putusan Praperadilan Nomor 14/Pid. Pra/2016/PN. Tjk)” (2017) 5:3 JURNAL POENALE. 
peradilan militer yang diperiksa secara koneksitas adalah perkara kasus korupsi Technical Assistance Contract (TAC) antara Pertamina dengan Ustraindo Petro Gas (UPG) dengan tersangka Ginanjar Kartasasmita. ${ }^{5}$ Tim penyidik koneksitas dalam perkara ini berjumlah 12 orang yang terdiri dari 5 orang dari unsur TNI (Oditur dan Puspom) dan 7 orang dari unsur Kejaksaan. Sedangkan perkara yang diperiksa tanpa melalui koneksitas adalah kasus tindak pidana korupsi pembelian Helikopter Auguswesland 101 (Helikopter AW 101) yang melibatkan lima orang pelaku dari kalangan militer yaitu Marsda SB, Marsma FA, Kol FTS, Letkol WW, dan Pelda SS dan satu orang dari kalangan sipil. ${ }^{6}$

Kasus korupsi dalam perkara pembelian Helikopter AW 101 salah satu tersangkanya melakukan upaya praperadilan yang mempermasalahkan tidak dibentuknya tim tetap dalam proses penanganan tindak pidana korupsi tersebut. ${ }^{7}$ Hal ini dapat menimbulkan ketidakpastian apakah tim tetap sebagai prosedur dari mekanisme koneksitas tesebut wajib dibentuk dalam penanganan tindak pidana korupsi yang dilakukan oleh masyarakat sipil dan anggota militer. Apabila terdapat upaya hukum maka hal tersebut secara tidak langsung akan menghambat proses penanganan korupsi itu sendiri terlebih lagi penanganan terhadap perkara korupsi yang melibatkan dua orang yang memiliki wilayah peradilan yang berbeda sehingga lebih rumit dalam hal penanganannya. Terdapat tindak pidana koneksitas yang seharusnya diperiksa oleh tim tetap koneksitas tetapi tidak diperiksa oleh tim tersebut memungkinkan penerapan yang bervariasi dan bisa bertolak belakang. ${ }^{8}$

Ada beberapa permasalahan dalam penulisan ini. Pertama, apakah dalam suatu perkara tindak pidana korupsi yang melibatkan pelaku yang masuk ruang lingkup peradilan umum dan peradilan militer harus diperiksa secara koneksitas. Kedua, apakah implikasi yuridis penetapan tersangka dalam perkara tindak pidana korupsi yang melibatkan pelaku yang masuk ruang lingkup peradilan umum dan peradilan militer tanpa melalui mekanisme koneksitas.

\section{PERATURAN KONEKSITAS DI DALAM PERATURAN PERUNDANG- UNDANGAN DI INDONESIA}

Moelyatno memberikan pengertian terkait hukum acara pidana atau hukum formil yakni hukum yang mengatur tata cara melaksanakan hukum materiil (hukum pidana). Artinya,

5 Hukumonline.com, Tim Koneksitas Terbentuk, Ginajar Akan Kembali Diperiksa, http://www.hukumonline.com/berita/baca/hol5542/tim-koneksitas-terbentuk-ginandjar-akan-kembalidiperiksa-, diakses 11 Mei 2018, Pukul 14.00 WIB.

6 Hukumonline, Penyidikan Koneksitas Disinggung dalam Praperadilan (Penanganan perkara antara sipil dan militer terpisah), http://www.hukumonline.com/berita/baca/lta013336a9ed4/penyidikan-koneksitasdisinggung-dalam-praperadilan, diakses 11 Mei 2018 Pukul 20.02 WIB.

7 Detik.com, KPK Tegaskan Penetapan Tersangka Kasus 101 Sah, http://news.detik.com/berita/d3715398/kpk-tegaskan-penetapan-tersangka-kasus-heli-aw-sah, diakses 11 Mei 2018, Pukul 20.12 WIB.

8 Nasional, supra note 2., hlm. 16. 
hukum acara pidana adalah hukum yang mengatur tata cara melaksanakan/ mempertahankan hukum pidana materiil. ${ }^{9}$ Di dalam KUHAP tidak disebutkan secara eksplisit terkait pengertian hukum acara pidana, namun hanya dijelaskan beberapa bagian dari hukum acara pidana yaitu penyelidikan, penyidikan, penuntutan, mengadili, praperadilan, putusan pengadilan, upaya hukum, penyitaan, penggeledahan, penangkapan, dan penahanan. Ada tiga fungsi pokok hukum acara pidana yaitu mencari dan menemukan kebenaran, pengambilan putusan oleh hakim, pelaksanaan putusan yang telah diambil. ${ }^{10}$ Hal ini juga merupakan fungsi hukum acara pidana yang mana selain menegakkan hukum formil juga menemukan kebenaran adanya tindak pidana dan pelaku tindak pidana dalam perkara tindak pidana koneksitas, termasuk tindak pidana koneksitas terkait korupsi.

Tindak pidana koneksitas adalah tindak pidana yang dilakukan oleh masyarakat sipil bersama-sama anggota militer, dimana orang/masyarakat sipil tersebut seharusnya yang berwenang mengadilinya adalah peradilan umum, sedangkan anggota militer diadili oleh peradilan militer.." Bagi militer diadakan peradilan khusus dengan memperhatikan faktor khusus yang terdapat dalam bidang kemiliteran. ${ }^{12}$ Hal ini berkaitan dengan kerahasiaan negara dalam dunia militer yang harus dijaga sebab berkaitan dengan keamanan negara itu sendiri.

Koneksitas berasal dari bahasa latin "Connexio". ${ }^{13}$ Yang memiliki arti suatu perkara pidana dilakukan bersama-sama oleh warga sipil dan anggota militer yang diperiksa oleh peradilan umum kecuali apabila kerugian yang ditimbulkan oleh tindak pidana tersebut terletak pada kepentingan militer, maka diadili oleh peradilan militer. ${ }^{14}$ Acara pemeriksaan koneksitas atau peradilan koneksitas merupakan mekanisme yang diterapkan terhadap tindak pidana di mana terdapat penyertaan baik turut serta (deelneming) atau secara bersama-sama (made dader) yang melibatkan pelaku orang sipil dan pelaku orang yang berstatus sebagai militer. ${ }^{15}$ Dalam hal ini juga berlaku pada penanganan perkara koneksitas tindak pidana korupsi.

Adapun penanganan tindak pidana yang diperiksa melalui koneksitas diatur diantaranya di dalam Undang-Undang Nomor 5 Tahun 1950, Undang-Undang Nomor 14 Tahun 1970, Surat Keputusan Bersama Menteri Kehakiman, Menhankam/Pangab, Ketua Mahkamah Agung, Jaksa Agung, Undang-Undang Nomor 3 Tahun 1975, Undang-undang Nomor 8 Tahun 1981 tentang Hukum Acara Pidana, Undang-Undang Nomor 31 Tahun 1997

\footnotetext{
Andi Sofyan \& Abd Asis, "Hukum Acara Pidana Suatu Pengantar" (2013) Yang menerbitkan PT Rangkang Education: Yogyakarta., hlm. 3.

Ibid., hlm. 7.

"l Faisal Salam, "Moch., SH, MH" (2004) Peradilan Militer di Indonesia., hlm. 148.

12 Nasional, supra note 2., hlm. l.

13 Sumaryanti, Peradilan Koneksitas di Indonesia: Suatu Tinjauan Ringkas (Bina Aksara,1987). hlm. 26.

14 Ibid.

15 Chk Parluhutan Sagala, "Tinjauan Putusan terhadap Penyimpangan Ketentuan Hukum Acara Pemeriksaan Koneksitas"., http://www.dilmil-jakarta.go.id/?p=2906, diakses 11 Mei 2018, Pukul 09.00 WIB.
} 
tentang Peradilan Militer, Undang-Undang Nomor 16 Nomor 2004 tentang Kejaksaan, Undang-Undang Nomor 48 Tahun 2009 tentang Kekuasaan Kehakiman. Dalam KUHAP pemeriksaan koneksitas diatur di dalam Bab XI tentang koneksitas tepatnya pada Pasal 89, 90, 91, 92,93 serta $94 . .^{16}$

Dalam pasal-pasal tersebut diatur bahwa tindak pidana yang dilakukan bersamasama oleh mereka yang termasuk lingkungan peradilan umum dan lingkungan peradilan militer diperiksa dan diadili dalam lingkungan peradilan umum kecuali menurut Keputusan Menteri Pertahanan dan Keamanan (Menhankam) dengan persetujuan Menteri Kehakiman (Menkeh) perkara itu harus diperiksa dan diadili oleh pengadilan militer. Selanjutnya penyidikan perkara pidana tersebut dilakukan oleh suatu tim tetap ${ }^{17}$ yang dibentuk dengan surat keputusan bersama Menhankam dan Menkeh yang terdiri dari penyidik peradilan umum, polisi militer dan oditur militer (Otmil) atau oditur militer tinggi (Otmilti) sesuai dengan wewenang mereka dan hukum yang berlaku untuk penyidikan perkara pidana. Pasal 90 mengenai penelitian bersama oleh jaksa atau jaksa tinggi dan Otmil atau Otmilti atas hasil penyidikan tim tersebut. Kemudian pada Pasal 91 diatur mengenai wewenang mengadili menurut titik berat kerugian yang ditimbulkan, yaitu apabila titik berat kerugiannya terletak pada kepentingan sipil maka diperiksa dalam lingkup peradilan umum sedangkan apabila titik berat kerugiannya terletak pada kepentingan militer maka diperiksa dalam lingkup peradilan militer. Adapun aturanaturan dalam KUHAP pada prinsipnya sama dengan aturan yang ada di dalam UndangUndang Nomor 31 Tahun 1997 tentang Peradilan Militer tepatnya pada pasal 198, 199, 200, 201, 202 dan 203. ${ }^{18}$

Adapun terkait dengan pembentukan tim tetap koneksitas sebagaimana yang diatur di dalam Pasal 89 ayat (3) KUHAP dan Pasal 198 ayat (3) UU Peradilan Militer terdapat aturan pelaksananya yaitu surat keputusan Menhankam dan Menkeh Nomor K.10/M/XII/1993 dan Nomor : M.57.PR.09.03/1983 tentang Pembentukan Tim Tetap. ${ }^{19}$ Pada Pasal 4 ayat (3) surat keputusan bersama tersebut menyebutkan bahwa ketua tim tetap bertugas mengkoordinasikan dan melakukan pengawasan terhadap pelaksanaan penyidikan oleh Tim Tetap yang bersangkutan agar dapat berjalan lancar, terarah, berdaya guna dan berhasil guna. ${ }^{20}$ Pasal 7 SKB Menhankam dan Menkeh Nomor K.10/M/XII/1993 dan Nomor : M.57.PR.09.03/1983 menyebutkan bahwa dalam hal perkara koneksitas merupakan tindak pidana tertentu yang diatur dalam undang-undang tertentu dengan ketentuan khusus acara pidana sebagaimana dimaksud dalam Pasal 284 ayat (2) KUHAP.

16 Lihat Pasal 89, 90, 91, 92, 93 serta 94 Undang-Undang Nomor 8 Tahun 1981 tentang Hukum Acara Pidana.

17 Tim tetap adalah badan penyidik perkara pidana koneksitas baik terhadap tindak pidana umum maupun tindak pidana khusus/tertentu yang diatur di dalam Undang-Undang. (Jakarta; Badan Pembinaan Hukum Nasional Departemen Kehakiman Republik Indonesia, 1994/1995), hlm. 18.

18 Lihat Pasal 198, 199, 200, 201,202, 203 Undang-Undang Nomor 31 Tahun 1997 tentang Peradilan Militer.

19 Erwin Wibowo \& others, PENYIDIKAN PERKARA KONEKSITAS TINDAK PIDANA KORUPSI (PhD Thesis, UNIVERSITAS AIRLANGGA, 2006) [unpublished].

20 Ibid. 
Unsur kejaksaan atau pejabat penyidik lainnya yang berwenang berdasarkan peraturan perundang-undangan diikutsertakan sebagai tim tetap.

Surat keputusan bersama $a^{2 l}$ yang merupakan pelaksanaan dari Pasal 89 ayat (3) KUHAP dan Pasal 198 ayat (3) UU Peradilan Militer, sedang pada ayat (2) dari masingmasing pasal tersebut di atas, ditentukan bahwa Tim Tetap tersebut melakukan penyidikan sesuai dengan wewenang masing-masing menurut hukum yang berlaku untuk penyidikan perkara pidana. Apabila suatu perkara koneksitas diperiksa melalui mekanisme koneksitas maka aparat penyidik koneksitas terdiri dari tim tetap yang terdiri atas penyidik kejaksaan, polri, polisi militer dan oditur. Yang mana cara bekerjanya disesuaikan dengan penggarisan dan batas-batas wewenang dan apabila dilakukan pemeriksaan secara terpisah atau splitsing maka perkara dikembalikan ke penyidik yang berwenang menurut hukum acara yang sesuai dengan peradilannya masing-masing. Dalam hal suatu perkara tidak dilakukan splitsing, maka penyidikan koneksitas akan berlanjut pada penuntutan dan pemeriksaan persidangan sesuai dengan peraturan mekanisme koneksitas yang ada di dalam peraturan perundang-undangan.

Adapun dalam proses penanganan korupsi kurang lebih alurnya sama dengan yang diatur di dalam peraturan perundang-undangan di atas. Selain berlaku peraturan perundang-undangan di atas berlaku juga undang-undang tindak pidana korupsi lainnya misalnya Undang-Undang Nomor 31 Tahun 1999 jo. Undang-Undang Nomor 20 Tahun 2001 tentang Tindak Pemberantasan Tindak Pidana Korupsi (UU Tipikor), UndangUndang Nomor 30 Tahun 2002 tentang Komisi Pemberantasan Tindak Pidana Korupsi (UU KPK) dan Undang-Undang 46 Tahun 2009 tentang Pengadilan Tindak Pidana Korupsi. Sehingga dalam hal ini apabila terdapat kasus korupsi sebagaimana yang dimaksud Pasal 11 UU KPK ${ }^{22}$ dan melibatkan pelaku masyarakat sipil dan anggota militer maka pemeriksaannya selain melibatkan unsur pejabat yang menangani perkara yang

${ }^{21}$ Surat keputusan bersama Menteri Pertahanan dan Keamanan dan Menteri Kehakiman Nomor: KEP.10/M/XII/1983- Nomor KEP.57.PR.09.03 Tahun 1983 yang pada pokoknya menentukan mengenai kedudukan, susunan dan tugas tim tetap koneksitas adapun kedudukannya ada di pusat dan di daerah yang mana berisi pejabat yang terdiri dari unsur peradilan umum dan peradulan militer; Penunjukan anggota dan ketua tim tetap koneksitas pusat dilakukan dengan menerbitkan Surat Perintah oleh Kapolri, Dan Puspom dan Orjen Abri, Penunjukan Anggota Tim Tetap Koneksitas Pengadilan Tinggi dan Tim Koneksitas Pengadilan Negeri dilakukan dengan menerbitkan Surat Perintah oleh Komandan/ Kepala Kesatuan, Dinas Jawatan masing-masing, Ketua Tim Tetap Koneksitas Pusat dijabat oleh salah seorang dari Anggota Tim Tetap Koneksitas Pusat secara bergantian dimulai dari unsur polri, polisi militer, dan oditur berlaku salama l (satu) tahun dan penggantian ketua tim koneksitas pusat dilakukan pada tiap tanggal 1 April. Di dalam Praktik sering terjadi ketidakpastian yang disebabkan tidak dipenuhinya prosedur dalam ketentuan di atas.

22 Pasal 11 UU KPK menyebutkan dalam melaksanakan tugas sebagaimana yang dimaksud dalam Pasal 6 huruf c menyatakan bahwa Komisi Pemberantasan Korupsi berwenang melaukan penyelidikan, penyidikan, dan penuntutan tindak pidana korupsi yang: (a). Melibatkan aparat penegak hukum, penyelenggara Negara dan orang lain yang ada kaitannya dengan tindak pidana korupsi yang dilakukan oleh aparat penegak hukum atau penyelenggara Negara. (b) Mendapat perhatian yang meresahkan masyarakat; dan/atau. (c) Menyangkut kerugian Negara paling sedikit Rp 1.000.000.000,00 (satu milyar rupiah). 
berasal dari militer, dalam perkara tersebut juga melibatkan anggota KPK. KPK juga memiliki kewenangan mengkoordinasikan atau mengendalikan penanganan perkara tindak pidana korupsi sebagaimana yang diatur di dalam Pasal $42 \mathrm{KPK} .{ }^{23}$ Adapun alur mekanisme koneksitas dapat dilihat dalam bagan dibawah ini:

\section{Penyidikan}

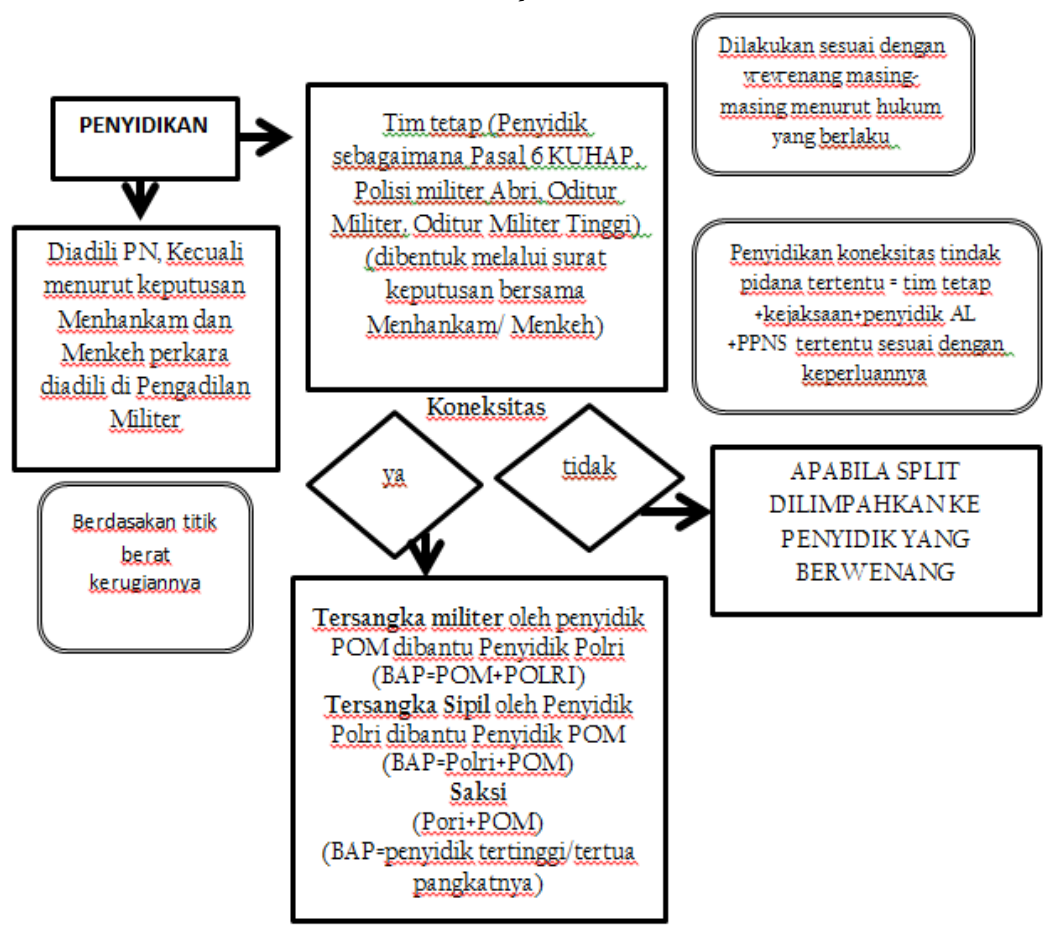

Dalam mekanisme koneksitas, pengadilan yang berwenang mengadili adalah Pengadilan Negeri. Dalam hal pemeriksaan koneksitas yang diadili di lingkungan mahkamah militer harus mendapatkan persetujuan dari Menhankam atau Menkeh. Penentuan pengadilan mana yang berwenang didasarkan pada titik berat kerugian yang ditimbulkan apakah kepentingan militer atau kepentingan masyarakat sipil/kepentingan umum. ${ }^{24}$ Penyidikan ${ }^{25}$ pada mekanisme koneksitas dilakukan oleh suatu tim tetap yang terdiri dari unsur penyidik sipil dan unsur penyidik militer.

Terkait dengan mekanisme koneksitas pada tindak pidana tertentu atau tindak pidana khusus yang terdapat pada undang-undang tindak pidana tertentu atau tindak pidana

23 Pasal 42 KPK menyatakan bahwa KPK berwenang mengkoordinasika dan mengendalikan penyelidikan, penyidikan dan penuntutan tindak pidana korupsi yang dilakukan bersama-sama oleh orang yang tunduk pada peradilan militer dan peradilan umum

24 Nasional, supra note 2. hlm. 16.

25 Dalam hal dimulainya penyidikan yaitu pada saat: (a) Tim tetap mengetahui atau menerima laporan secara langsung tentang adanya tindak pidana koneksitas; (b) Menerima pelimpahan dari Penyidik Polri; (c) Menerima Pelimpahan dari Penyidik POM TNI; (d)Menerima Pelimpahan dari Penyidik Tindak Pidana tertentu yang diatur di dalam undang-undang. (Nasional, supra note 2., hlm. 17). 
khusus maka penyidikan dilakukan oleh tim tetap ditambah dengan penyidik kejaksaan, Angkatan Laut dan PPNS tertentu sesuai dengan kebutuhannya. ${ }^{26}$ Pasal 1 angka 2 KUHAP menyatakan bahwa penyidikan adalah serangkaian tindakan penyidik dalam hal dan menurut cara yang diatur dalam undang-undang ini untuk mencari serta mengumpulkan bukti yang dengan bukti itu membuat terang tentang tindak pidana yang terjadi dan guna menemukan tersangkanya. Proses penyidikan dalam hal ini merupakan rangkaian hukum acara pidana yang berhubungan erat dengan penetapan tersangka. Penetapan tersangka ini dapat dilakukan sesudah ditemukannya bukti permulaan yang cukup sebagaimana yang tercantum dalam putusan MK nomor 21/PUU-XII/2014.

\section{Penuntutan $^{27}$}

Pasal 1 angka 7 KUHAP disebutkan bahwa penuntutan adalah tindakan penuntut umum untuk melimpahkan perkara pidana ke pengadilan negeri yang berwenang dalam hal dan menurut cara yang diatur dalam undang-undang ini dengan permintaan supaya diperiksa dan diputus oleh hakim di pengadilan. Jaksa/jaksa tinggi dan Otmil/Otmilti mengadakan penelitian bersama yang hasilnya dituangkan dalam Berita Acara Pendapat Bersama (BAP) atas hasil penyidikan tim tetap untuk menetapkan pengadilan mana yang akan memeriksa/mengadili perkara tindak pidana koneksitas. ${ }^{28}$ Dalam penelitian bersama tersebut dapat terjadi persesuaian pendapat maupun perbedan pendapat terkait pengadilan mana yang berwenang memeriksa dan mengadili. ${ }^{29}$

${ }^{26}$ Ibid., hlm. 18.

27 Untuk menetapkan pengadilan mana yang berwenang, atas hasil penyidikan tim tetap itu diadakan penelitian bersama antara Jaksa/Jaksa Tinggi dan Oditur Militer (Ormil)/ Oditur Militer Tinggi (Ormilti) yang hasilnya dituangkan dalam Berita Acara Pendapat bersama, jika pendapatnya bersesuaian maka Jaksa/Jaksa Tinggi melaporkan kepada jaksa Agung dan Ormil/Ormilti melaporkan hal tersebut pada Oditur Jenderal ABRI kemudian jika terdapat ketidaksesuaian atau terjadi perbedaan pendapat antara Jaksa Agung dan Oditur Jenderal Abri ( Orjen Abri) maka pendapat jaksa Agung yang menentukan.

28 Nasional, supra note 2., hlm. 19.

29 Ibid. 


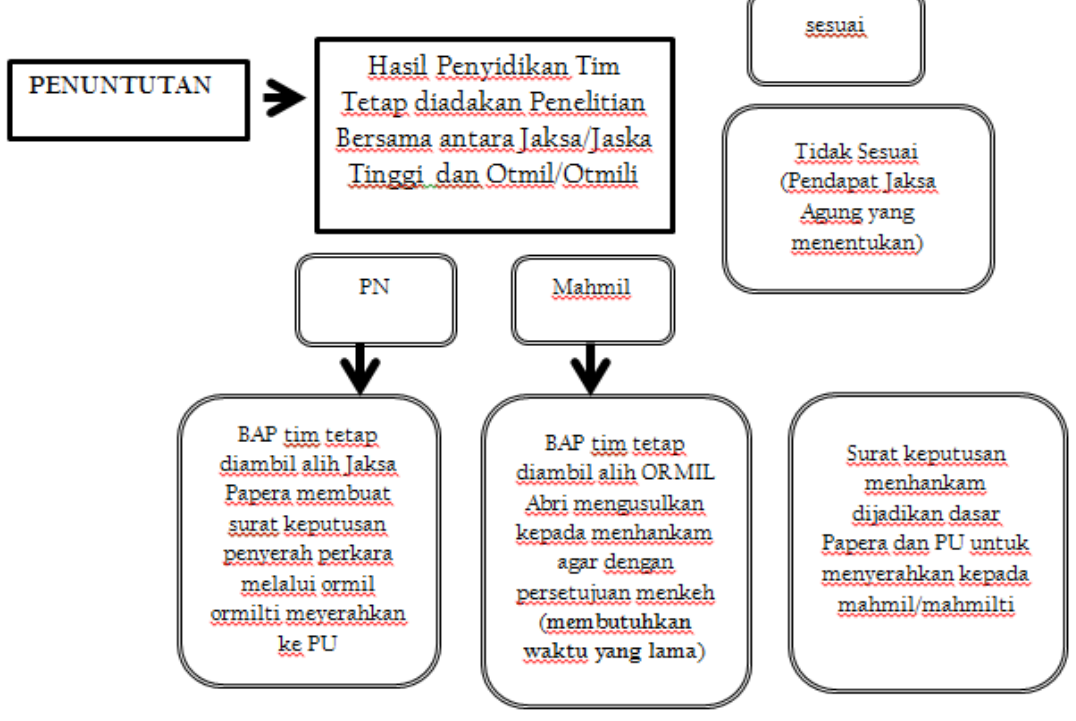

\section{Pemeriksaan Sidang ${ }^{30}$}

Untuk pemeriksaan persidangan adalah pemeriksaan terhadap seorang terdakwa di Persidangan. Dalam hal ini, yang berwenang mengadili adalah hakim. Pasal 1 angka 9 menyatakan mengadili adalah serangkaian tindakan hakim untuk menerima, memeriksa, dan memutus perkara pidana berdasarkan asas bebas, jujur, tidak memihak di sidang pengadilan dalam hal dan menurut cara yang diatur dalam undang-undang ini. Baik perkara tersebut diperiksa/diadili oleh Pengadilan Negeri maupn Mahkamah Militer (Mahmil)/Mahkamah Militer Tinggi (Mahmilti) yang mengadili adalah majelis hakim yang terdiri dari sekurang-kurangnya tiga orang hakim.

Sehingga untuk menjawab rumusan masalah pertama terkait apakah dalam suatu perkara tindak pidana korupsi yang melibatkan pelaku yang masuk ruang lingkup peradilan umum dan yang masuk ruang lingkup peradilan militer harus diperiksa secara koneksitas maka jawaban dari permasalahan tersebut adalah tidak harus. Hal ini dikarenakan dalam penanganan tindak pidana koneksitas penanganannya bisa dilakukan

30 Dalam buku yang berjudul Hukum Acara Pidana Suatu Pengantar di dalam sub bab Acara Pemeriksaan Perkara Pidana di Pengadilan disebutkan bahwa dalam pemeriksaan sidang pengadilan terdapat proses pemeriksaan identitas terdakwa, proses pembacaan surat dakwaan oleh penuntut umum, proses pembacaan eksepsi atau tangkisan oleh terdakwa, proses pembuktian (alat-alat bukti dalam perkara pidana sebagaimana yang terdapat dalam Pasal 184 ayat (1) KUHAP yang terdiri dari keterangan saksi, keterangan ahli, alat bukti surat, alat bukti petunjuk, dan keterangan terdakwa), Proses Penuntutan, Pledoi atau Pembelaan, Tambahan Penuntutan, Tambahan Pembelaan, Acara Pengambilan Keputusan (Musyawarah Majelis Hakim), Keputusan Pegadilan (Hakim) kemudian setelah putusan dibacakan oleh hakim maka proses selanjutnya adalah pelaksanaan putusan pengadilan dan pengawasan dan pengamatan pelaksanaan putusan pengadilan. (Sofyan \& Asis, supra note 7., hlm. 31l-34l) 
secara terpisah atau splitsing. ${ }^{3 l}$ Sehingga dalam hal perkara tidak diperiksa melalui koneksitas maka penanganannya menurut hukum peradilan masing-masing dari pelaku baik sipil maupun militer. Apabila pelaku dari masyarakat sipil maka diberlakukan hukum dalam peradilan umum yaitu pengadilan negeri dan pelaku yang termasuk anggota militer diperiksa menurut hukum dalam peradilan militer. Yang terpenting dalam penetapan tersangka adalah ditemukannya bukti permulaan yang cukup. Dalam penanganan koneksitas tindak pidana korupsi yang dilakukan oleh unsur KPK dan unsur militer, KPK memiliki kewenangan sebagaimana dalam Pasal 42 UU KPK yakni mengendalikan dan mengkoordinasikan perkara koneksitas. Dalam hal ini KPK dapat mempertimbangkan perlu atau tidaknya dibentuk tim koneksitas dalam penanganan tindak pidana korupsi yang berdasarkan pada SKB Menhankam dan Menkeh.

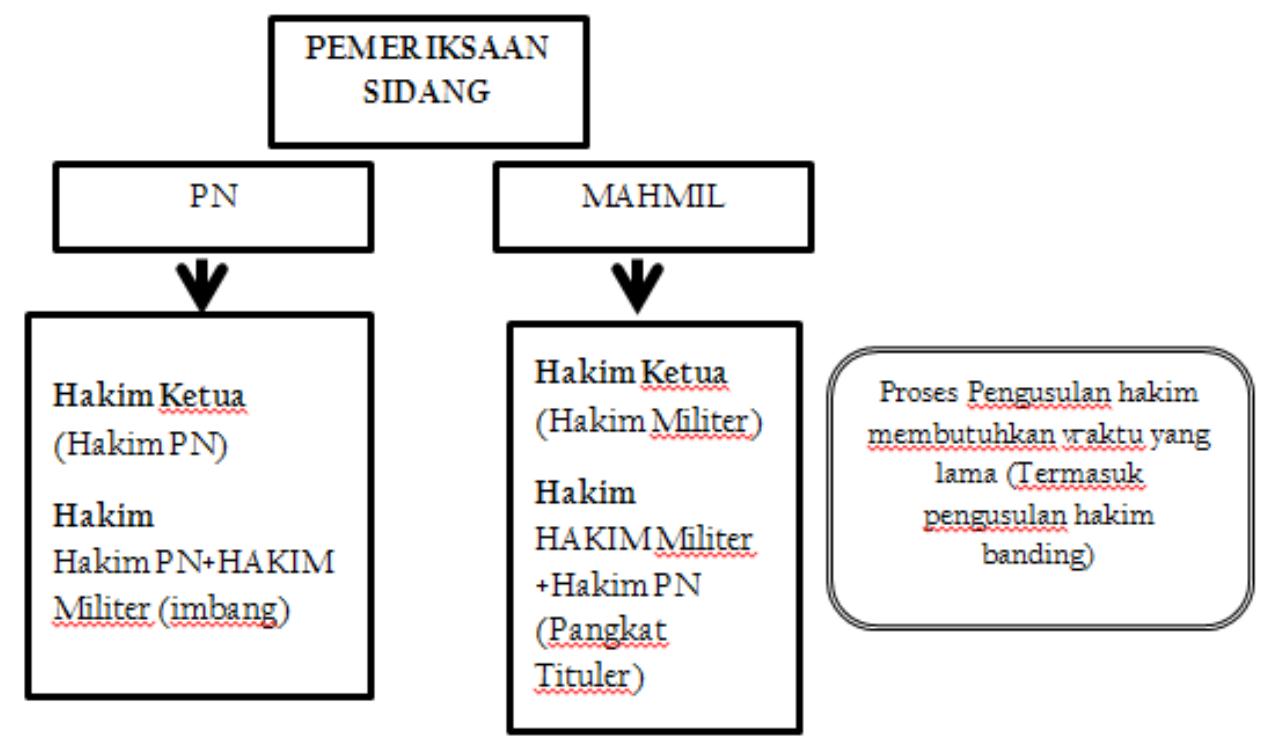

31 Dalam Pasal 142 KUHAP dinyatakan bahwa dalam hal penuntut umum menerima satu berkas perkara yang memuat beberapa tindak pidana yang dilakukan oleh beberapa orang tersangka yang tidak termasuk dalam ketentuan Pasal 14l, Penuntut Umum dapat melakukan penuntutan terhadap masing-masing terdakwa secara terpisah. Adapun ketentuan dalam Pasal 141 KUHAP menyatakan bahwa "Penuntut umum dapat melakukan penggabungan perkara dan membuatnya dalam satu surat dakwaan, apabila pada waktu yang sama atau hampir bersamaan ia menerima beberapa berkas dalam hal: a. beberapa tindak pidana dilakukan oleh seseorang yang sama dan kepentingan pemeriksaan tidak menjadikan halangan terhadap penggabungannya;b. beberapa tindak pidana yang bersangkut paut dengan yang lain ; c. Beberapa tindak pidana yang tidak bersangkut paut satu dengan yang lain, akan tetapi yang satu dengan yang lain itu ada hubungannya, yang dalam hal ini penggabungan tersebut perlu bagi kepentingan pemeriksaan. " Dalam splitsing sebenarnya pemisahan perkara itu harus terdiri dari beberapa tindak pidana yang berbeda namun dilakukan oleh beberapa orang dalam waktu yang sama. Namun dalam praktiknya splitsing juga dilakukan terhadap beberapa pelaku tindak pidana tetapi hanya satu tindak pidana dilakukan (Hukum Online, Pemisahan Berkas Perkara Pidana (Splitsing). 


\section{IMPLIKASI YURIDIS PENETAPAN TERSANGKA TANPA MELALUI MEKANISME KONEKSITAS}

Korupsi disebut sebagai kejahatan yang sulit tersentuh (invisible crime) sehingga dalam hal ini pemberantasannya memerlukan kebijakan politik yang jelas dan tegas. ${ }^{32}$ Tindak pidana korupsi bukan lagi dikatakan sebagai kejahatan extraordinary crime melainkan terdapat pergesera paradigma ke arah criminal against humanity. Hal inilah yang menjadi dasar dibentuknya KPK. KPK dibentuk melalui amanat Pasal 43 Undang-Undang Nomor 30 Tahun 1999 jo. Undang-Undang Nomor 20 Tahun 2001.

Pada kasus sidang praperadilan kasus Helikopter AW 101, hakim menolak permohonan praperadilan dari salah satu tersangka yakni Direktur PT. Dirgantara Jaya Mandiri, Irfan Saleh dalam kasus dugaan Helikopter AW 101. Hakim menyatakan bahwa dalam kasus tersebut KPK telah sesuai dengan bukti permulaan cukup yang sebagaimana diatur di dalam putusan Mahkamah Konstitusi. Hakim mendasarkan pada Pasal 42 UU KPK yang menyatakan bahwa KPK berwenang mengkoordinasikan dan mengendalikan penyelidikan, penyidikan dan penuntutan tindak pidana korupsi yang dilakukan bersamasama oleh orang yang tunduk pada peradilan militer dan peradilan umum. Sehingga dalam hal ini, KPK dapat menetapkan tersangka tanpa adanya pembentukan tim koneksitas yang didasarkan pada SKB Menhankam dan Menkeh. ${ }^{33}$ Hal ini sejalan dengan tugas dan wewenang KPK yang terdapat pada Pasal 6 huruf a UU KPK ${ }^{34}$ dan Pasal 7 UU KPK. ${ }^{35} \mathrm{Hal}$ ini merupakan implikasi bahwa KPK sebagai lembaga independen dan bebas dari pengaruh kekuasaan manapun ${ }^{36}$ sehingga dalam hal ini KPK dapat mengesampingkan adanya SKB Menhankam dan Menkeh terkait pembentukan tim tetap. Selain itu, KPK juga merupakan lembaga superbody ${ }^{37}$ dalam penanganan tindak pidana korupsi. ${ }^{38}$ Termasuk wewenang

32 Tri Agung Kristanto \& Irwan Suhanda, Jangan Bunuh KPK, Perlawanan Terhadap Usaha Pemberantasan Korupsi (Jakarta: Kompas, 2009)., hlm. 21.

33 _. 2017, Ini Reaksi KPK Praperadilan Tersangka Pembelian Hei AW 101 Ditolak, https://www.merdeka.com/peristiwa/ini-reaksi-kpk-praperadilan-tersangka-pembelian-heli-awl01-

ditolak.html, diakses 10 Mei 208, Pukul 12.00 WIB.

34 Pasal 6 huruf a menyebutkan bahwa KPK mempunyai tugas melakukan koordinasi dengan instansi berwenang melakukan pemberantasan tindak pidana korupsi.

35 Pasal 7 Undang-undang KPK menyebutkan bahwa dalam melaksanakan tugas dan koordinasi sebagaimana yang dimaksud dalam Pasal 6 huruf a, Komisi Pemberantasan Korupsi berwenang: (a) Mengkoordinasikan penyelidikan, penyidikan, dan penuntutan tindak pidana korupsi; (b) Menetapkan sistem pelaporan dalam kegiatan pemberantasan tindak pidana korupsi; (c) Meminta informasi tentang kegiatan pemberantasan tindak pidana korupsi kepada instansi terkait; (d) Melaksanakan dengar pendapat atau pertemuan dengan instansi yang berwenang melakukan pemberantasan tindak pidana korupsi, dan (e) Meminta laporan instansi terkait mengenai pencegahan tindak pidana korupsi.

36 Hukumonline, Penyidikan Koneksitas Disinggung dalam Praperadilan (Penanganan perkara antara Sipil dan militer terpisah), http:/www.hukumonline.com/berita/baca/lt5a013336a9ed4/penyidikankoneksitas-disinggung-dalam-praperadilan, diakses 11 Mei 2018, Pukul 20.02 WIB.

37 Lembaga superbody merupakan lembagayang memiiki kewenangan yang lebih besar dibandingkan dengan kewenangan lembaga lain.

38 Mohammad Hatta, KPK dan Sistem Peradilan Pidana (Penerbit Liberty, 2014)., hlm. 18. 
penyidikan maupun wewenang penetapan tersangka yang tunduk pada hukum peradilan umum pada pemeriksaan acara koneksitas. Meskipun demikian, KPK tetap harus memperhatikan ketentuan di dalam KUHAP, bahwa dalam hal penetapan tersangka dilakukan setelah penyidik berhasil mengumpulkan sekurang-kurangnya dua alat bukti dan telah berhasil membuat terang tindak pidana yang terjadi. ${ }^{39}$ Sehingga meskipun tidak dibentuk tim koneksitas akan tetapi apabila sudah terdapat bukti permulaan yang cukup sebagaimana ketentuan yang terdapat dalam peraturan perundang-undangan/dalam putusan MK nomor 21/PUU-XII/2014 seseorang sudah dapat ditetapkan sebagai tersangka. Dalam hal praperadilan diatur di dalam Peraturan Pemerintah Nomor 27 Tahun 1983 yang menyatakan bahwa perkara koneksitas didasarkan pada perundang-undangan yang berlaku di masing-masing peradilan.

Kasus praperadilan kasus Helikopter AW 101, selain hakim menggunakan Pasal 42 sebagai dasar ditolaknya permohonan terkait ketidakabsahan penetapan tersangka, Juliandi yang merupakan salah satu tim biro hukum KPK menyatakan bahwa penanganan yang dilakukan oleh KPK dan Pejabat TNI adalah penanganan yang dilakukan secara terpisah. Dalam hal ini, KPK memberikan beberapa putusan yang pemeriksaannya dilakukan secara terpisah antara lain putusan dalam kasus cek pelawat dengan terdakwa/ terpidana atas nama Miranda Swaray Gultom, putusan dalam kasus Bakamla atas nama terdakwa/terpidana Muhammad Adami Okta, putusan dalam kasus Bakamla atas nama terdakwa/terpidana Brigjen (TNI) Teddy Hernayadi, serta putusan dalam kasus Bakamla atas nama terdakwa/terpidana Fahmi Darmawansyah. ${ }^{40}$

Terkait implikasi yuridis penetapan tersangka tanpa melalui mekanisme koneksitas adalah sah atau tidak batal demi hukum sebab perkara tindak pidana koneksitas dapat diperiksa secara terpisah (Split). ${ }^{41}$ Sehingga dalam hal ini boleh dilakukan pemeriksaan perkara secara terpisah maupun tidak dilakukan pemeriksaan secara terpisah dalam hal ini dilakukannya pemeriksaan secara koneksitas. Namun dalam hal pemeriksaan secara splitsing, terdapat beberapa kekurangan dalam pelaksanaannya. Dalam hal ini, pemeriksaan tidak menjadi satu rangkaian mekanisme koneksitas yang utuh sebagaimana yang diatur di dalam peraturan perundang-undangan pada prosesnya.

Dalam hal pelaku yang ditindak oleh KPK dan militer, KPK memiliki kewenangan koordinasi dengan aparat penegak hukum lainnya, sehingga dalam hal ini boleh dibentuk tim koneksitas maupun tidak dibentuk tim koneksitas. Dalam hal dapat dilakukannya penetapan tersangka pada mekanisme koneksitas sama halnya dengan penetapan

39 Marcus Priyo Gunarto, 2018, Polemik Perintah Penetapan Tersangka, http://www.mediaindonesia.com/read/detail/155747-polemik-perintah-penetapan-tersangka, diakses 11 Mei 2018, Pukul 15.00 WIB.

40 Hukumonline, supra note 6.

${ }^{41}$ Pemeriksaan perkara secara split maka masing-masing lembaga yang berwenang dalam arti apabila pelaku dari sipil diperiksa melalui peradilan umum dan apabila pelaku dari militer diperiksa melalui pengadilan militer. 
tersangka pada mekanisme peradilan yang bukan koneksitas yaitu harus berdasar pada bukti pemulaan yang cukup. ${ }^{42}$ Tersangka menurut Pasal 1 angka 14 KUHAP adalah seorang yang karena perbuatannya atau keadaannya berdasarkan bukti permulaan patut diduga sebagai pelaku tindak pidana. ${ }^{43}$ Definisi ini juga diatur di dalam ketentuan Pasal 1 angka 10 Peraturan Kapori Nomor 14 Tahun 2012 tentang Manajemen Penyidikan Tindak Pidana.

Bukti permulaan yang cukup tersebut merupakan wujud perlindungan dari hak asasi $^{44}$ seseorang agar sebelum seseorang ditetapkan sebagai tersangka telah dapat memberi keterangan secara seimbang. Dalam hal ini guna menghindari kesewenangwenangan dari penyidik. ${ }^{45}$ Fungsi bukti permulaan yang cukup adalah sebagai persyaratan untuk dilakukannya penyidikan dan menetapkan seseorang sebagai tersangka. ${ }^{46}$ Setelah penetapan seseorang menjadi tersangka dapat dilakukan upaya penangkapan dan penahanan. Dilakukannya penahanan dapat menimbulkan potensi pelanggaran terhadap hak atas rasa aman dan perlindungan dari ancaman ketakutan untuk berbuat atau tidak berbuat sesuatu sesuai dengan Pasal 28 G ayat (1) UUD 1945. ${ }^{47}$

Maksud dan tujuan dari mekanisme koneksitas adalah memberikan jaminan bagi terlaksananya peradilan koneksitas yang cepat dan adil, walaupun ada kemungkinan bahwa proses yang ditempuh tidak semudah pada perkara pidana biasa. ${ }^{48}$ Alasan mengapa mekanisme koneksitas sering diabaikan oleh para pihak sebab perkara koneksitas harus menunggu keputusan dari Menhankam dan disetujui oleh Menkeh. Kemudian menunggu hasil penelitian dari tim penyidik yang dibentuk apakah perkara diadili pada peradilan umum atau peradilan militer sehingga diperlukan waktu lama dalam menyelesaikan perkara koneksitas ini. ${ }^{49}$ Dalam hal ini termasuk waktu dalam proses pengusulan hakim koneksitas.

42 Bukti permulaan yang cukup dalam putusan MK nomor 21/PUU-XII/2014 menyatakan inkonstitusional bersyarat terhadap frasa "bukti permulaan", bukti permulaan yang cukup", dan "bukti yang cukup" dalam Pasal 1 angka 14, Pasal 17 dan Pasal 21 ayat (1) sepanjang dimaknai minimal dua alat bukti sesuai Pasal 184 KUHAP. Sedangkan dalam Pasal 184 KUHAP, Alat bukti yang sah ialah keterangan saksi, keterangan ahli, surat, petunjuk, keterangan terdakwa.

43 Pasal 1 Angka 4, Undang-Undang Nomor 8 Tahun 1981 tentang Hukum Acara Pidana.

44 Perlindungan hak asasi manusia merupakan wujud dari perlindungan hukum yang ad a di Negara hukum. Julius Stahl menjelaskan bahwa konsep Negara hukum yang disebut sebagai rechstaat mencakup Beberapa kriteria antara lain: Perlindungan Hak Asasi Manusia, Pembagian Kekuasaan, dan Pemerintahan Berdasarkan Undang-Undang dan peradilan Tata Usaha Negara.

45 Hukumonline, Arti "Bukti Permulaan Yang Cukup" Dalam Hukum Acara Pidana, http://www.hukumonline.com/klinik/detail/lt5940eb06leb6l/arti-bukti-permulaan-yang-cukup-dalamhukum-acara-pidana, diakses 11 Mei Pukul 10.00 WIB.

46 Ibid.

47 Hukumonline, Pernyataan Polisi Tentang Penetapan Tersangka, http://www.hukumonline.com/klinik/ detail/lt54d46fe50a6b5/pernyataan-polisi-tentang-penetapan-tersangka, diakses 10 Mei 2018, Pukul 20.00 WIB.

48 Sagala, supra note 13.

49 Menurut Kesimpulan dalam buku yang berjudul "Analisis dan Evaluasi Hukum Tentang Putusan Pengadilan Militer Dalam Perkara Koneksitas" bahwa tim tetap yang diatur di dalam KUHAP maupun peraturan menteri sulit untuk diterapkan karena ketidakpastian terkait prosedur dan tata laksana 
Dalam penyelesaian tindak pidana korupsi harus dilakukan secara cepat dan tepat. Sebagaimana Pasal 25 UU Tipikor yang menyebutkan bahwa penyidikan, penuntutan dan pemeriksaan dalam sidang pengadilan dalam perkara tindak pidana korupsi harus didahulukan dari perkara lain guna penyelesaian secepatnya. Ketentuan tersebut memiliki relevansi dengan asas peradilan sederhana, cepat, dan biaya ringan. Korupsi merupakan kejahatan extraordinary crime yang dalam tindak pidana korupsi yang dirugikan adalah perekonomian dan keuangan negara yang diperuntukkan bagi kesejahteraan masyarakat. Oleh sebab itu, penanganan perkara tindak pidana korupsi didahulukan dibandingkan dengan penanganan perkara lainnya.

Secara khusus hukum acara dalam pengadilan tindak pidana korupsi diatur di dalam UU Pengadilan Tipikor, ketentuan umum lain yang tidak diatur dalam undang-undang khusus menggunakan KUHAP. Secara umum hukum acara pengadilan tindak pidana korupsi tetap mengacu pada asas-asas hukum pidana dan hukum acara pidana yang ada. ${ }^{50}$ Sehingga dalam hal ini meskipun tidak ada ketentuan secara eksplisit yang mengatur, asasasas hukum acara pidana khusus. Dengan demikian, asas peradilan sederhana, cepat, dan biaya ringan yang termasuk salah satu asas hukum acara pidana umum juga berlaku pada hukum acara pidana khusus.

Adapun kebutuhan akan biaya pemeriksaan koneksitas diajukan oleh ketua tim tetap yang bersangkutan kepada Badan Pelaksana Hukum Angkatan Bersenjata Republik Indonesia (Babinkum ABRI) dengan tembusan Orjen ABRI. ${ }^{51}$ Dalam praktik proses untuk mendapatkan biaya dari Babinkum ABRI ternyata memakan waktu yang lama sehingga memperlambat proses penyidikan. ${ }^{52}$ Dalam hal ini, tidak sesuai dengan asas peradilan sederhana, cepat dan biaya ringan sebagai asas dalam sistem peradilan di Indonesia.

Suatu tindak pidana yang dilakukan oleh pelaku yang berbeda lingkungannya seperti dalam perkara koneksitas ini, apabila diadili secara terpisah akan menimbulkan kesukaran baik dalam mencapai rasa keadilan, materi hukum yang bersangkutan maupun mengenai keseragaman dalam penuntutan dan penjatuhan pidana. ${ }^{53}$ Dalam hal ini, menurut penulis juga berkaitan dengan penetapan tersangka yang sangat berkaitan dengan proses penyidikan perkara tindak pidana korupsi pada peradilan koneksitas.

Dalam perkara koneksitas sering dilakukan pemeriksaan terpisah (Split) dan tidak jarang bahwa perkara koneksitas yang seharusnya penyidikannya dilakukan oleh tim tetap

penyidikan yang diakukan oeh para penyidik Tim Tetap Koneksitas baik yang bersangkutan dengan batasan kewenangannya, format administrasi penyidikan/ pemberkasan dan yang menyangkut serah terima jabatan sebagai ketua tim tetap, kurang efektif dan terjangkaunya fungsi pengendalian dan pengawasan, belum ada kejelasan terkait pengaturan tentang aplikasi kewenangan dan kegiatan tim koneksitas dalam kegiatan penyidikan. (Nasional, supra note 2., hlm. 27).

50 Ermansyah Djaja \& Tarmizi, Meredesain pengadilan tindak pidana korupsi: implikasi Putusan Mahkamah Konstitusi nomor 012-016-019/PPU-IV/2006 (Sinar Grafika, 2010)., hlm. 52.

${ }^{51}$ Nasional, supra note 2., hlm. 26.

52 Ibid.

53 Djaja \& Tarmizi, supra note 50., hlm 52. 
dilakukan oleh penyidik yang bukan masuk kategori tim tetap. ${ }^{54}$ Hal ini dapat menimbulkan ketidakjelasan sebab dalam peraturan perkara koneksitas baik di dalam KUHAP maupun di dalam UU Peradilan Militer sudah ditentukan mekanisme terkait penanganan koneksitas. Sebagaimana Pasal 89 KUHAP dan Pasal 198 UU Peradilan Militer diatur apabila terdapat perkara tindak pidana koneksitas maka diperiksa dan diadili oleh pengadilan dalam lingkup peradilan umum kecuali jika menurut keputusan Menhankam dengan persetujuan Menkeh perkara itu harus diperiksa dan diadili oleh pengadilan dalam lingkungan peradilan militer. ${ }^{55}$ Penyidikan perkara pidana dilaksanakan oleh suatu tim tetap yang terdiri dari penyidik dalam lingkungan peradilan umum dan peradilan militer, sesuai dengan wewenangnya masing-masing menurut hukum yang berlaku. Dalam hal penyidikan perkara pidana kemudian tim tersebut dibentuk dengan surat keputusan bersama Menhankam dan Menkeh. Namun dalam pelaksanaannya tidak dilakukan sesuai dengan ketentuan tersebut, namun dilaksanakan oleh penyidik sipil apabila pelaku tindak pidana koneksitas dari masyarakat sipil dengan hukum acara yang berlaku di lingkungan peradilan umum dan dilaksanakan oleh penyidik militer apabila pelaku tindak pidana koneksitas dari anggota militer dengan hukum acara yang berlaku di lingkungan peradilan militer tanpa dibentuk tim tetap terlebih dahulu.

Dengan adanya kompleksitas permasalahan dari koneksitas menjadikan pilihan penyelesaian diselesaikan melalui splitsing (pemisahan) tanpa menggunakan mekanisme koneksitas. Karena kompleksitas mekanisme koneksitas tersebut dalam suatu perkara

54 Nasional, supra note 2., hlm. 16-17.

55 Pasal 90 KUHAP menyatakan: (1) Untuk menetapkan apakah pengadilan dalam lingkungan peradilan militer atau pengadilan dalam lingkungan peradilan umum yang akan mengadili perkara pidana sebagaimana dimaksud dalam Pasal 89 ayat (1), diadakan penelitian bersama oleh jaksa atau jaksa tinggi dan oditur militer atau oditur militer tinggi atas dasar hasil penyidikan tim tersebut pada Pasal 89 ayat (2); (2) Pendapat dan penelitian bersama tersebut dituangkan dalam. berita acara yang ditandatangani oleh para pihak sebagaimana dimaksud dalam ayat (1); (3) Jika dalam penelitian bersama itu terdapat persesuaian pendapat tentang pengadilan yang berwenang mengadili perkara tersebut, maka hal itu dilaporkan oleh jaksa atau jaksa tinggi kepada Jaksa Agung dan oleh oditur militer atau oditur militer tinggi kepada Oditur Jenideral Angkatan Bersenjata Republik Indonesia.

Kemudian Pasal 91 (1) KUHAP menyatakan: (1) Jika menurut pendapat sebagaimana dimaksud dalam Pasal 90 ayat (3) titik berat kerugian yang ditimbulkan oleh tindak pidana tersebut terletak pada kepentingan umum dan karenanya perkara pidana itu harus diadili oleh pengadilan dalam lingkungan peradilan umum, maka perwira penyerah perkara segera membuat surat keputusan penyerahan perkara yang diserahkan melalui oditur militer atau oditur militer tinggi kepada penuntut umum, untuk dijadikan dasar mengajukan perkara tersebut kepada pengadilan negeri yang berwenang; (2) Apabila menurut pendapat itu titik berat kerugian yang ditimbulkan oleh tindak pidana tersebut terletak pada kepentingan militer sehingga perkara pidana itu harus diadili oleh pengadilan dalam lingkungan peradilan militer, maka pendapat sebagaimaña dimaksud dalam Pasal 90 ayat (3) dijadikan dasar bagi Oditur Jenderal Angkatan Bersenjata Republik Indonesia untuk mengusulkan kepada Menteri Pertahan dan Keamanan, agar dengan persetujuan Menteri Kehakiman dikeluarkan keputusan Menteri Pertahanan dan Keamanan yang menetapkan, bahwa perkara pidana tersebut diadili oleh pengadilan dalam lingkungan peradilan militer; (3) Surat keputusan tersebut pada ayat (2) dijadikan dasar bagi perwira penyerah perkara dan jaksa atau jaksa tinggi untuk menyerahkan perkara tersebut kepada mahkamah militer atau mahkamah militer tinggi. 
tindak pidana yang dilakukan bersama-sama oleh masyarakat sipil dalam proses penyelesaiannya terdapat dua mekanisme yaitu perkara koneksitas yang penyelesaian perkaranya secara koneksitas yaitu pelaku masyarakat sipil dan pelaku anggota militer diajukan kepada Mahkamah Militer atau Pengadilan Negeri. Sedangkan perkara koneksitas yang penyelesaian perkaranya terpisah (splitsing) yaitu pelaku masyarakat sipil diselesaikan melalui pengadilan negeri dan pelaku anggota militer diselasaikan melalui Mahkamah Militer. ${ }^{56}$

Tim tetap yang memeriksa perkara koneksitas terdiri atas unsur peradilan umum dan peradilan militer yang memeriksa perkara koneksitas dalam satu lingkup peradilan diperiksa dalam lingkup peradilan umum saja atau diperiksa dalam lingkup peradilan militer dengan keputusan Menhankam dengan persetujuan Menkeh. Di mana dalam penentuan peradilannya didasarkan pada titik berat kerugian apakah pada kepentingan umum atau kepentingan militer, pemeriksaan yang dilakukan oleh tim koneksitas dapat membuat suatu perkara diperiksa menjadi satu rangkaian pemeriksaan koneksitas yang utuh dalam hal pemeriksaan dan pembuktian para pelaku, baik pelaku yang berasal dari masyarakat sipil maupun oleh anggota militer. Namun dalam pelaksanaan pemeriksaan tindak pidana koneksitas, pembentukan tim koneksitas ini sering diabaikan sebab pembentukan tim koneksitas yang dinilai rumit dan memakan waktu yang lama.

Apabila ditinjau menurut teori kebijakan pidana, terkait peraturan pembentukan tim tetap koneksitas dapat dirumuskan lebih baik lagi agar dapat diimplementasikan dengan mudah dalam penerapannya sehingga tercapainya keadilan. Kebijakan hukum pidana dari Marc Ancel menyebut istilah "kebijakan" diambil dari istilah "policy" yang berasal dari bahasa inggris sehingga istilah "Kebijakan Hukum Pidana" sama artinya dengan istilah " Politik Hukum Pidana”. Selanjutnya Marc Ancel mendefinisikan arti Politik Hukum Pidana atau "penal policy" adalah suatu ilmu sekaligus seni yang bertujuan untuk memungkinkan peraturan hukum positif dirumuskan secara lebih baik. Definisi hukum positif (the positive rules) menurut Marc Ancel adalah peraturan perundang-undangan hukum pidana. ${ }^{57}$ Peraturan perundang-undangan yang dimaksud adalah peraturan perundang-undangan hukum pidana, baik hukum pidana materiil maupun hukum pidana formil. Terkait dengan peraturan yang mengatur tentang mekanisme koneksitas perlu diatur mengenai jangka waktu pembentukan tim koneksitas, koordinasi pembentukan tim koneksitas dan seharusnya diperjelas mengenai perkara tertentu yang diperbolehkan dilakukannya splitsing. Misalnya kasus tindak pidana ringan tetapi harus dilakukannya koordinasi meskipun tidak dibentuk tim tetap.

Selain Marc Ancel, Soedarto juga mengemukakan bahwa dengan melaksanakan politik hukum pidana sama halnya dengan membentuk atau menyusun peraturan

\footnotetext{
56 Sumaryanti, supra note 1l. hlm. 76.

57 Barda Nawawi Arief, Bunga Rampai Kebijakan Hukum Pidana, (Citra Aditya Bakti: 2010), hlm. 27.
} 
perundang-undangan pidana yang paling baik dalam arti memenuhi syarat keadilan dan daya guna di dalam masyarakat. Hal ini digunakan sebagai usaha untuk mewujudkan peraturan perundang-undangan pidana yang sesuai dengan keadaan dan situasi pada saat ini dan untuk masa yang akan datang. ${ }^{58}$ Tindak pidana korupsi yang berkembang tidak hanya dilakukan oleh masyarakat sipil saja namun juga dilakukan bersama-sama oleh mereka yang berlainan lingkungan peradilannya sehingga diperlukan pengaturan yang mengandung adanya kepastian hukum guna terciptanya keadilan.

Pernyataan Marc Ancel dan Sudarto memiliki relevansi dengan permasalahan dalam pengaturan mekanisme koneksitas yang dinilai masih memiliki beberapa masalah dalam penerapannya sehingga kedepannya diperlukan suatu peraturan terkait mekanisme koneksitas yang memiliki ketentuan sesuai dengan asas-asas dalam sistem peradilan pidana khususnya asas keadilan, asas kepastian, asas kemanfaatan serta asas peradilan sederhana, cepat dan biaya ringan.

\section{KESIMPULAN}

Peraturan koneksitas di dalam peraturan perundang-undangan yang berlaku di Indonesia yang salah satu prosedurnya adalah dibentuknya tim tetap dalam penanganan perkara. Termasuk prosedur penanganan perkara tindak pidana korupsi yang dilakukan bersamasama oleh mereka yang tunduk pada peradilan umum dan peradilan militer. Dalam suatu perkara tindak pidana korupsi yang melibatkan pelaku yang masuk ruang lingkup peradilan umum dan peradilan militer tidak harus diperiksa melalui mekanisme pemeriksaan koneksitas karena dapat diperiksa melalui mekanisme splitsing. Adapun Implikasi yuridis penetapan tersangka tanpa melalui mekanisme koneksitas adalah tetap sah sebab dalam hal dapat atau tidaknya seseorang ditetapkan menjadi seorang tersangka adalah berdasarkan ditemukanya bukti permulaan yang cukup. Di dalam Pasal 42 UU KPK, salah satu kewenangan KPK adalah mengkoordinasikan serta mengendalikan penanganan perkara koneksitas, sehingga KPK dapat berkoordinasi dengan penyidik dari militer saja tanpa membentuk tim tetap. Faktanya, perkara yang diperiksa melalui mekanisme koneksitas sebagaimana yang diatur di dalam peraturan perundang-undangan dirasa memiliki beberapa kekurangan antara lain membutuhkan waktu yang lama sehingga dirasa mengabaikan asas peradilan sederhana, cepat dan biaya ringan. Sehingga dalam hal ini penyidik lebih memilih pemeriksaan secara splitsing padahal mekanisme koneksitas merupakan mekanisme yang dapat menjadikan perkara tersebut proses penangannya menjadi satu rangkaian pemeriksaan koneksitas yang utuh yang dapat mewujudkan keadilan bagi pelaku yang berbeda wilayah peradilannya. Dalam hal ini menyangkut mengenai tuntutan, pembuktian maupun penjatuhan pidana. Sehingga kedepannya perlu

\footnotetext{
${ }^{58}$ Ibid., hlm. 45.
} 
dibentuk pengaturan koneksitas dalam penetapan tim tetap misalnya terkait jangka waktu pembentukan tim tetap dan koordinasi pembentukan tim tetap antara pejabat peradilan sipil dan pejabat peradilan militer berdasar pada asas peradilan sederhana, cepat dan biaya ringan serta berdasarkan pada asas keadilan.

\section{DAFTAR PUSTAKA}

Andi Sofyan \& Abd Asis, "Hukum Acara Pidana Suatu Pengantar" (2013), PT Rangkang Education: Yogyakarta.

Barda Nawawi Arief, Bunga Rampai Kebijakan Hukum Pidana, (Citra Aditya Bakti: 2010).

Chk Parluhutan Sagala, "Tinjauan Putusan terhadap Penyimpangan Ketentuan Hukum Acara Pemeriksaan Koneksitas", http://www.dilmil-jakarta.go.id/?p=2906, diakses 11 Mei 2018, Pukul 09.00 WIB.

Detik.com, KPK Tegaskan Penetapan Tersangka Kasus 101 Sah, http://news.detik.com/berita/d-3715398/kpk-tegaskan-penetapan-tersangka-kasusheli-aw-sah, diakses 11 Mei 2018, Pukul 20.12 WIB.

Ermansyah Djaja \& Tarmizi, Meredesain pengadilan tindak pidana korupsi: implikasi Putusan Mahkamah Konstitusi nomor 012-016-019/PPU-IV/2006 (Sinar Grafika, 2010).

Erwin Wibowo \& others, PENYIDIKAN PERKARA KONEKSITAS TINDAK PIDANA KORUPSI (PhD Thesis, UNIVERSITAS AIRLANGGA, 2006) [unpublished].

Evi Hartanti, Tindak pidana korupsi (Sinar Grafika, 2005).

Faisal Salam, (2004) Peradilan Militer di Indonesia.

Hukumonline, Penyidikan Koneksitas Disinggung dalam Praperadilan (Penanganan perkara antara sipil dan militer terpisah), http://www.hukumonline.com/berita/baca/lta013336a9ed4/penyidikan-koneksitasdisinggung-dalam-praperadilan, diakses 11 Mei 2018 Pukul 20.02 WIB.

Hukumonline, Arti “ Bukti Permulaan Yang Cukup” Dalam Hukum Acara Pidana, http://www.hukumonline.com/klinik/detail/lt5940eb06leb6l/arti-bukti-permulaanyang-cukup-dalam-hukum-acara-pidana, diakses 11 Mei Pukul 10.00 WIB.

Hukumonline, Tim Koneksitas Terbentuk, Ginajar Akan Kembali Diperiksa, http://www.hukumonline.com/berita/baca/hol5542/tim-koneksitas-terbentukginandjar-akan-kembali-diperiksa-, diakses 11 Mei 2018, Pukul 14.00 WIB.

Hukumonline, Penyidikan Koneksitas Disinggung dalam Praperadilan (Penanganan perkara antara Sipil dan militer terpisah), http://www.hukumonline.com/berita/ baca/lt5a013336a9ed4/penyidikan-koneksitas-disinggung-dalam-praperadilan, diakses 11 Mei 2018, Pukul 20.02 WIB.

Indonesia Badan Pembinaan Hukum Nasional, Analisis dan evaluasi hukum tentang putusan pengadilan militer dalam perkara koneksitas (Badan Pembinaan Hukum Nasional, Departemen Kehakiman, 1996). 
Mohammad Hatta, KPK dan sistem peradilan pidana (Penerbit Liberty, 2014).

Media Indonesia, Polemik Perintah Penetapan Tersangka, http:// www.mediaindonesia.com/read/detail/155747-polemik-perintah-penetapantersangka, diakses 11 Mei 2018, Pukul 15.00 WIB.

Merdeka.com Ini Reaksi KPK Praperadilan Tersangka Pembelian Hei AW 101 Ditolak, https://www.merdeka.com/peristiwa/ini-reaksi-kpk-praperadilan-tersangkapembelian-heli-awl01-ditolak.html, diakses 10 Mei 208, Pukul 12.00 WIB.

Romli Atmasasmita, Korupsi, good governance, dan komisi anti korupsi di Indonesia (Departemen Kehakiman dan HAM RI, Badan Pembinaan Hukum Nasional, 2002).

Sumaryanti, Peradilan Koneksitas Di Indonesia: Suatu Tinjauan Ringkas (Bina Aksara,1987).

Tri Agung Kristanto \& Irwan Suhanda, Jangan Bunuh KPK, Perlawanan Terhadap Usaha Pemberantasan Korupsi (Jakarta: Kompas, 2009).

Wanda Rara Farezha, "Analisis Putusan Hakim Praperadian dalam Perkara Tindak Pidana Korupsi (Studi Putusan Praperadilan Nomor 14/Pid. Pra/2016/PN. Tjk)” (2017) 5:3 Jurnal Poenale. 
246 | Penetapan Tersangka pada Peradilan Koneksitas dalam Perkara Tindak Pidana Korupsi

This page is intentionally left blank 